\title{
Marketing of Information Products \& Services in Kurukshetra University Library in the Disciplines of Social Science: A study
}

\author{
Anil Kumar (Gold Medalist) \\ (Librarian, Swift Group of Colleges, Rajpura, Patiala (Punjab), India) \\ M.Sc. Library, M. Phil Library Sc. \& Pursuing Ph. D in K.U.K)
}

\begin{abstract}
The present study has been undertaken to assess the marketing of information products \& services in kurukshetra university library in the disciplines of social science. A well structured questionnaire was distributed among the research-scholars and teachers of seven departments viz History, Public administration, Social Work, Economics, psychology, Sociology, Political Science under the Social Science in K.U.K. The responses were gathered from 120 users $(40$ Teachers and 80 Research Scholars).The findings of the survey reveal useful facts about the marketing of information products \& services in kurukshetra university library.43.33\% of the respondents were always use the library daily, $14.16 \%$ sometimes and14.16\% respondents were always using the library once in a week, 6.66\% twice in a week. Only 20.83\% respondents were always using the library by occasionally. $94.16 \%$ respondents were use the library for research needs, $70.83 \%$ education purpose only. On the basis of the findings, it was suggested that in order to improve the library personnel should be made aware of the concepts and principles of modern marketing. So provide better provision for the library staff to attend in-service and career advancement courses and also most of the respondents were willing to pay for information products \& services imply that they rely on the quality of information products than the existing products, which were freely available. So kurukshetra university library have to restructure or develop some of the existing products and services and to start new services based on market analysis. Most of respondents were suggested that Kurukshetra University library should take necessary steps to install plasma or LCD screen in the library entrance hall to display notices and information (photographs, videos etc.) of their information services and products.
\end{abstract}

Keywords: Information products and services, Kurukshetra University, Library services, Marketing, Products, use.

\section{Introduction}

In the present age of information technology, libraries \& information centers have become profit making organizations due to adoption of new technological storage, processing, retrieval \& services. Instead of the user approaching for information services in the libraries or information centers, the information must reach the user's place of work; whether it is a classroom, the research laboratory, the home or any other place of activity in any field of life (Kotler and Andreasen, 1995). Before 1970, the concept of marketing was confined almost exclusively to organizations supplying products rather than services. Although the idea of applying marketing principles to library activity was realized by S. R. Ranganathan in 1930s himself and on the basis of which the five laws of library science were formulated by him (Mandal, Poddar and Choudhury, 1998). Libraries are playing important role to market their information services for the benefit for their users to use new technologies, to anticipate the trends.

\section{PRODUCTS \& SERVICES}

The products refers to sources of information and knowledge contents that are available in electronic forms such as CD- ROMs, interactive video, films, audio digital products, online publishing, public domain and commercial online databases available through internet and other databases available through various private network providers.

\section{MARKETING OF INFORMATION PRODUCTS \& SERVICES}

In a broad sense, marketing in the context of information products and services, may be defined as a concept of sensitively serving and satisfying the information needs of all those who are involved in education, scholarship, research and development, business, trade industry etc. Libraries should adopt marketing approach in the provision of library users. Nolan (1998) advises professional librarians to become 
entrepreneurs. According to her, many libraries whether special, corporate, private or public are facing a similar scenario: "do more with less and less."

\section{DEFINATION}

Stanton (1981) "marketing is a total system of interacting business activities to plan, price, promote and distribute want satisfying products \& services and present to potential customers".

Kotler (1996) Marketing means working with markets to actualize potential exchanges for the purpose of satisfying human needs and wants. It is the process of planning and executing the conception, pricing, promotion and distribution of goods, services and ideas to create exchanges with target groups that satisfy customer and organizational objectives.

\section{MARKETING STRATEGIES OF LIC's}

Marketing strategy is a comprehensive, integrated and coordinated plan that combines four marketing elements, commonly called the '4Ps' they are: Product, Price, Place and Promotion and 3Ps of the marketing mix are: Participants, Physical Evidence and Process.

- Product (Service): Defining the characteristics (quality, design, reputation, credibility, authority) of library product or service to meet the needs of the customers (users).

- Price: Deciding on a pricing strategy. If the library decides not to change for a given service, it is useful to realize that this is still a pricing strategy. Identifying the total cost of the user is a part of price element.

- Promotion: this includes advertising, personal selling (i.e. attending exhibitions), sales promotions (i.e. special; offers), and atmospherics (creating the right impression through the working environment). Public relation is included within promotion by many marketing people.

- Place: looking at the location (i.e. library), distribution channel (where a service is delivered), geographical coverage, telecommunication, travels, etc. we can extend the number of P's- the two, which are usually seen as useful additions for services (including information services).

- People: The essential ingredient (staff/personnel) for providing effective information service among users. Good information services are not likely to be delivered by people who are unskilled or de motivated.

- Process: The way in which the user gets hold of the service (i.e. the way in which a document or a search can be ordered). The library or information services for users in a convenient way (i.e. the help of information technology may be taken if need).

- Physical Evidence: The environment in which the reference and information services are delivered that facilitates the performance and communication of the service (Koontz and Rockwood, 2001).

\section{Review Of Related Literature} of research.

The review of the literature is an important part of scientific approach and is carried out in all the areas

VIJ (2012) reviewed studies has been undertaken to discuss the development of information society, the libraries have also gone through a transformation. Libraries were much like a service industry where user satisfaction was supreme. The author dealt with the marketing of library products and services in India. Due to the pressure of growing technologies, expectations of users, high maintenance costs and reducing budget, the need of marketing of library products \& services has increased considerably. The marketing process of library products and services needed strategic planning. The major finding of the survey revealed to cover all those activities based on techniques, obstacles \& requirement of effective professional skills in marketing of library products and services in India.

Anagreh (2012) reviewed studies has been undertaken to discuss the concept of research appeals for the library to be a recreational and scientific organization consistent with the local community, and interacts within the framework of the market mechanism qualifying it to face the challenges of the modern era and as well as creating self-funding library. The traditional presentation of the library services was not in line with the requirements of the marketing concepts. So, the concept of library as service organization has to be modified to meet consumer's perceptions of the present generations through highlighting the library as an attractive organization. The development of the activity of the university library required providing further additional services; such as photocopy services, cinema halls, and entertainment facilities for children, cafeteria, as well as providing the library with natural landscaping scenes and scientific atmospheres that encouraged the educational process. Enabling the library to play its leading role as a productive organization in accordance with the "supply and demand mechanism" required also reformulation its marketing mix which allows the library to disseminate 
knowledge, raise the scientific level of the population categories and delivery of information to the largest number of citizens.

Makori (2011) conducted a study of marketing of information products \& services in research libraries in Kenya. The author found that the literature survey were currently published articles \& the researcher's professional experience. The major finding of the survey reveal useful facts about the marketing was basic and essential management process for promoting information products and services in university research libraries. The study emphasized the marketing avails university research libraries were unique opportunity to provide quality, demand based, and user oriented information products \& services.

Gupta (2010) surveyed the introductory studies remarked on the definition of marketing, the evolution of library \& information services (LIS) marketing was explained. The author found that the research described that how marketing was applied to LIS over the years. Marketing was also related to other concepts used in the management of LIS. The major finding of the survey revealed a useful fact about the role of professional associations in diffusing marketing theory was portrayed $\&$ the importance of education addressed. The entry ends with a reflection on the future on marketing for LIS.

Aharony (2009) Reviewed studies has been undertaken to explore the attitudes of school, academic \& public librarians towards marketing libraries. A structure of questionnaire examined whether personality characteristics such as empowerment, extroversion and resistance to change influence librarians attitudes towards the marketing of libraries. The study was gathered from 150 participants by using the research tools as: a personal details questionnaire, extroversion/introversion questionnaire, attitudes towards marketing a library questionnaire, a resistance to change questionnaire and an empowerment questionnaire. The major findings of the survey reveal useful facts that research was the positive correlation between personal characteristics: empowerment, extroversion and resistance to change and attitudes towards marketing libraries. He emphasized the idea that librarians of all branches should be exposed to marketing concepts in order to maintain their central position as information providers despite and within the new technologies.

Popoola (2008) Reviewed studies has been undertaken to discuss faculty awareness \& use of library information products and services in South West Nigeria Universities. Systematic random sampling method was used to select 446 faculty members from a population of 4,459 in the universities. A questionnaire formed the major instrument for data gathering. The response rate achieved was $89.7 \%$ and the reliability coefficient of the questionnaire used was $0.72 \%$. The study emphasized the idea that there was a significant difference in faculty awareness of available library products \& services.

Munshi (2008) conducted a case study of marketing approach aimed at determining the needs, wants and demands of the target clients through designing and delivering appropriate products and services more effectively for the purpose of achieving organizational goals and objectives. It was an attempt to conceptualize the strategic approaches of marketing mix to library and information centers. Finally, it recognized some benefits of proposed marketing plan.

Amritpal Kaur (2007) Reviewed studies has been undertaken to assess the attitude of users towards the marketing of information services and products of university research libraries. A structured questionnaire was distributed among the library users of four universities of Punjab and Chandigarh. The responses were gathered from 1237 users (241 teachers, 271 research scholars and 725 postgraduate students). The major findings of the survey revealed useful facts about marketing of information products and services. More than $61 \%$ were willing to pay for developed information services and $57 \%$ for developed information products.

Sharma and Choudhary (2005) conducted a case study of All India Management Association (AIMA) Library. The authors found that experience of marketing of information services and products was very encouraging at the AIMA Library. The users' satisfaction assessment was overall good, which was evident from the fact that users were constantly asking for information through all possible means say e-mail, telephone, fax, mail and personal visits. Revenues generation of AIMA Library through products and services was also good and it was moving towards self sufficiency. The author's opinion that at present when library budgets were shrinking, marketing of its products was earnestly required.

Kanaujia (2004) Conducted a case study of reflect the gradual change in the need and use of the marketing concepts in libraries \& Information centres (LICs) and its fruitful effects in the service to the library users, and studies marketing of information products/services in LICs of R \& D Institutions of Council of Scientific \& Industrial Research (CSIR) of India. It discussed the role of these LICs including marketing approach, need and application of a marketing program with the help of a survey. For the survey data were collected through a detailed mailed questionnaire along with interviews. The major findings of the survey revealed useful facts that librarians have a positive attitude towards the different aspects of marketing of a library's information products/services. The study recommended that currently efforts for increasing user awareness and separate financial support were requisite for efficient marketing.

Neuhaus and Snowden (2003) conducted a case study of Rod Library of University of Northern Lowa. The Rod Library Marketing Committee created by Dean of Library Services in 1999 to better co-ordinate 
the library marketing efforts were able to heighten faculty and student awareness of library resources and services. Various marketing efforts and experiments such as promotional newsletters, e-mail postings, and student surveys were employed for the purpose.

Ganguly and Kar (2002) conducted a case study of Tata Energy and Research Institute (TERI), New Delhi and stated that TERI-LIC's experience of marketing was very encouraging. Its wide range of products and services was marketed and disseminated to the end user through an effective marketing strategy. Most of the services and products were price-based.

Tadasad and Talikoti (2000) surveyed the users of the City Central Library of Gulbarga to find out the extent of awareness and utilization of resources, services and facilities provided by the library. The findings of the survey revealed that a significant proportion of the users were unaware of the resources, services and facilities of the library. The study emphasized the need for organizing regular awareness program to increase the optimum utilization of the resources, services and facilities of the library.

Pandya (2001) conducted a survey of the M S University of Baroda to explore the feasibility of marketing library and information services and products. The findings of the survey revealed that almost all the respondents depend upon the library for satisfying their information requirements. More than $80 \%$ of the research scholars and $92 \%$ of the deposit members were ready to pay library membership fee on yearly basis which indicated that money was not a constraint if quality services and products were provided on time. Respondents ranging from $52 \%$ to $72 \%$ were ready to pay for value added services such as CD-ROM searches, on-line searches, translation service, e-mail, SDI and CAS which were likely to be introduced in future by the library.

\section{Research Methodology}

For the purpose of the study, a questionnaire was designed (Appendix-1). The questionnaire was pretested before using it with the survey population. All the respondents were given the same questionnaire irrespective of their status. The questionnaire was distributed to any those respondents who willingly agreed to participate in the study. The respondents were interviewed also to fill in the gaps, if any.

\section{OBJECTIVES OF THE STUDY}

The present study intends to investigate the following objectives:

- To examine and access the information products \& services provided by the kurukshetra university library in the disciplines of social science.

- To identify the information needs of Teachers and Research Scholars and willingness to pay for the Information products \& services by kurukshetra university library in the disciplines of social science.

- To investigate the knowledge of awareness of marketing of Information Product \& Services in kurukshetra university library in the disciplines of social science.

- To examine and understand the common problem faced by the users to access the information Product \& services in kurukshetra university library in the disciplines of social science.

\section{SCOPE OF THE STUDY}

The study is being undertaken in order to identify the usability of Marketing of information products \& services available in kurukshetra university library in the disciplines of Social Sciences. The study will include research scholars \& faculty of all the seven departments viz Economics, History, Political Science, Social Work, Public Administration, Sociology, \& also Psychology following under the Social sciences.

\section{STATEMENT OF THE PROBLEMS}

Documentation activities of a country are very much interred linked with the research \& developmental efforts of the country. Research libraries spend huge amounts every year in building up their collections and offering library services. But these are of no use if these are not used to satisfy information needs of the library users. Effective utilization of resources and services can be achieved through marketing approach. It can assist them in the task of designing, developing and delivering appropriate services and products. Therefore, it is inevitable to know the attitudes towards marketing of information products \& services among the librarian and users. Thus, the topic of my research is "MARKETING OF INFORMATION PRODUCTS \& SERVICES IN KURUKSHETRA UNIVERSITY LIBRARY IN THE DISCIPLINES OF SOCIAL SCIENCE: A STUDY 


\section{Analysis \& Interpretation:}

Table 1. Gender wise use the library products \& services

\begin{tabular}{|c|l|c|}
\hline S.N & Gender wise & Response No \% \\
\hline 01 & Male & $75(53.57)$ \\
\hline 02 & Female & $65(46.42)$ \\
\hline Cumulative Total & $\mathbf{1 4 0}(\mathbf{1 0 0})$ \\
\hline
\end{tabular}

Table 1. shows that among marketing of information products and services use the kurukshetra university library male respondents are $53.57 \%$ than female users which are $46.42 \%$.

Table 2. Status wise Use the library products \& services

\begin{tabular}{|c|l|c|}
\hline S.N & Status wise & Response No \% \\
\hline 01 & Professor & $18(15)$ \\
\hline 02 & Associates Professor & $05(4.16)$ \\
\hline 03 & Asst. Professor & $17(14.16)$ \\
\hline 04 & Research Scholars & $80(66.66)$ \\
\hline
\end{tabular}

Results in table 2. Show that marketing of information products and services use the kurukshetra university library more popular among research scholars and professors than junior faculty members. Out of total respondents $66.66 \%$ research scholars and $15 \%$ professors are use the library products \& services.

Table 3: frequency of Use the library

\begin{tabular}{|c|c|c|c|c|c|c|c|}
\hline S.N & \multicolumn{2}{|c|}{ Use the Library } & Always & Often & Usually & Sometimes & Never \\
\hline \multirow[t]{2}{*}{01} & \multirow[t]{2}{*}{ Daily } & $\mathbf{T}$ & $2(1.66)$ & $2(1.66)$ & $3(2.5)$ & $2(1.66)$ & - \\
\hline & & R.S & $15(12.50)$ & $10(8.33)$ & $20(16.66)$ & $15(12.50)$ & - \\
\hline \multirow[t]{2}{*}{02} & \multirow[t]{2}{*}{ Once in a Week } & $\mathbf{T}$ & $1(0.83)$ & - & $4(3.33)$ & - & - \\
\hline & & R.S & $2(1.66)$ & $5(4.16)$ & $5(4.16)$ & - & - \\
\hline \multirow[t]{2}{*}{03} & \multirow[t]{2}{*}{ Twice in a week } & $\mathbf{T}$ & - & - & - & - & - \\
\hline & & R.S & $2(1.66)$ & $2(1.66)$ & $4(0.83)$ & - & - \\
\hline \multirow[t]{2}{*}{04} & \multirow[t]{2}{*}{ Thrice in a week } & $\mathbf{T}$ & - & - & - & - & - \\
\hline & & R.S & - & - & - & - & - \\
\hline \multirow[t]{2}{*}{05} & \multirow[t]{2}{*}{ Four times in a week } & $\mathbf{T}$ & - & - & - & - & - \\
\hline & & R.S & - & - & - & - & - \\
\hline \multirow[t]{2}{*}{06} & \multirow[t]{2}{*}{ Five times in a week } & $\mathbf{T}$ & - & - & - & & - \\
\hline & & R.S & - & - & - & - & - \\
\hline \multirow[t]{2}{*}{07} & \multirow[t]{2}{*}{ Occasionally } & $\mathbf{T}$ & $11(4.16)$ & $7(1.66)$ & $7(1.66)$ & - & - \\
\hline & & R.S & - & - & - & - & - \\
\hline
\end{tabular}

\section{T= Teacher; R.S= Research Scholars}

Table 3. shows the respondents various availability available use the library. $43.33 \%$ respondents are always using the library daily, and $14.16 \%$ sometimes. In social science $14.16 \%$ users are always use the library once in a week, $6.66 \%$ twice in a week and also $20.83 \%$ respondents are always using the library by occasionally.

Table 4. Average time spend in the library

\begin{tabular}{|l|l|c|c|c|c|c|c|}
\hline S.N & \multicolumn{2}{|c|}{ Time Spend } & Always & Often & Usually & Sometimes & Never \\
\hline 01 & \multirow{2}{*}{ Less than 30 Min. } & T & - & $1(0.83)$ & - & $10(8.33)$ & - \\
\cline { 3 - 8 } & & R.S & $10(8.33)$ & $2(1.66)$ & $15(12.50)$ & $15(12.50)$ & - \\
\hline 02 & Between 30 M \& 2 & T & - & - & - & $29(24.16)$ & - \\
\cline { 2 - 8 } & Hours & R.S & $10(8.33)$ & $15(12.50)$ & $10(8.33)$ & $3(2.5)$ & - \\
\hline 03 & \multirow{2}{*}{ Between 2 \& 5 Hours } & T & - & - & - & - & - \\
\cline { 3 - 8 } & & R.S & - & - & - & - & - \\
\hline 04 & \multirow{2}{*}{ More than 5 hours } & T & - & - & - & - & - \\
\cline { 3 - 8 } & & R.S & - & - & - & - & - \\
\hline
\end{tabular}


Table 4. shows that social science teachers and research scholars are more time spend in the library. $29.16 \%$ respondents are 30 to 2 hours time spends in the library, $26.66 \%$ respondents are sometimes. Only $23.33 \%$ of the users spend less than 30 minutes, $20.83 \%$ sometimes time spends in the library.

Table 5. Purpose of use the library

\begin{tabular}{|c|c|c|c|c|c|c|c|}
\hline S.N & Purpose of Use $t$ & & Always & Often & Usually & Sometimes & Never \\
\hline \multirow[t]{2}{*}{01} & \multirow[t]{2}{*}{ Research needs } & $\mathbf{T}$ & $20(16.66)$ & $10(8.33)$ & $7(5.8)$ & $3(2.5)$ & - \\
\hline & & R.S & $40(33.33)$ & $20(16.66)$ & $16(13.33)$ & $4(3.33)$ & - \\
\hline \multirow[t]{2}{*}{02} & \multirow[t]{2}{*}{ Education } & $\mathbf{T}$ & $10(8.33)$ & $15(12.50)$ & $5(4.16)$ & $10(8.33)$ & - \\
\hline & & R.S & $40(33.33)$ & $10(8.33)$ & $5(4.16)$ & $25(20.83)$ & - \\
\hline \multirow[t]{2}{*}{03} & \multirow[t]{2}{*}{ Current Information } & $\mathbf{T}$ & $15(12.50)$ & $10(8.33)$ & $5(4.16)$ & $10(8.33)$ & - \\
\hline & & R.S & $25(20.83)$ & $5(4.16)$ & $5(4.16)$ & $25(20.83)$ & $10(8.33)$ \\
\hline \multirow[t]{2}{*}{04} & \multirow[t]{2}{*}{ Photocopy } & $\mathbf{T}$ & - & - & $10(8.33)$ & $25(20.83)$ & $5(4.16)$ \\
\hline & & R.S & $25(20.83)$ & $22(18.33)$ & $23(19.16)$ & $2(1.66)$ & $3(2.5)$ \\
\hline \multirow[t]{2}{*}{05} & \multirow[t]{2}{*}{ Newspaper } & $\mathbf{T}$ & $1(0.83)$ & $2(1.66)$ & $1(0.83)$ & $10(8.33)$ & $26(21.66)$ \\
\hline & & R.S & $20(16.66)$ & $5(4.16)$ & $3(2.5)$ & $10(8.33)$ & $2(1.66)$ \\
\hline \multirow[t]{2}{*}{06} & \multirow[t]{2}{*}{ Journals } & $\mathbf{T}$ & $10(8.33)$ & $5(4.16)$ & $20(16.66)$ & $2(1.66)$ & $3(2.5)$ \\
\hline & & R.S & $20(16.66)$ & $10(8.33)$ & $30(25.0)$ & $20(16.66)$ & - \\
\hline
\end{tabular}

Most of the respondents use the library for more than one purpose. The analysis shows that main purpose of use the library are research need. In social science $94.16 \%$ users are use the library for research needs, and education purpose are the second for which users use the library i.e. 70.83\%. Current information are the third purpose for using the library i.e. $54.16 \%$ users always and $29.16 \%$ sometimes. In social science $79.16 \%$ users are use the journals in kurukshetra university library.

Table 6. User Need to Information Services

\begin{tabular}{|c|c|c|c|c|c|c|c|}
\hline S.N & \multicolumn{2}{|c|}{ User Need to Information services } & Always & Often & Usually & Sometimes & Never \\
\hline \multirow[t]{2}{*}{01} & \multirow[t]{2}{*}{ CAS } & $\mathbf{T}$ & $25(20.83)$ & $10(8.33)$ & $2(1.66)$ & $1(0.83)$ & $2(1.66)$ \\
\hline & & R.S & $40(33.33)$ & $20(16.66)$ & $10(8.33)$ & $6(5.0)$ & $4(3.33)$ \\
\hline \multirow[t]{2}{*}{02} & \multirow[t]{2}{*}{ SDI } & $\mathbf{T}$ & $10(8.33)$ & $22(18.33)$ & $3(2.5)$ & $2(1.66)$ & $3(2.5)$ \\
\hline & & R.S & $30(25.0)$ & $25(20.83)$ & $5(4.16)$ & $4(3.33)$ & $16(13.33)$ \\
\hline \multirow[t]{2}{*}{03} & \multirow[t]{2}{*}{ Newspaper } & $\mathbf{T}$ & $1(0.83)$ & $5(4.16)$ & $10(8.33)$ & $20(16.66)$ & $4(3.33)$ \\
\hline & & R.S & $10(8.33)$ & $5(4.16)$ & $5(20.83)$ & $55(45.83)$ & $5(4.16)$ \\
\hline \multirow[t]{2}{*}{$\overline{04}$} & \multirow[t]{2}{*}{ Patents information } & $\mathbf{T}$ & $2(1.66)$ & $3(2.5)$ & $5(4.16)$ & $5(4.16)$ & $25(20.83)$ \\
\hline & & R.S & $4(3.33)$ & $6(5.0)$ & $1(0.83)$ & $24(20.0)$ & $45(37.50)$ \\
\hline \multirow[t]{2}{*}{05} & \multirow[t]{2}{*}{ Standards Inf. } & $\mathbf{T}$ & $2(1.66)$ & $1(0.83)$ & $3(2.5)$ & $10(8.33)$ & $24(20.0)$ \\
\hline & & R.S & $2(1.66)$ & $2(1.66)$ & $6(5.0)$ & $20(16.66)$ & $50(41.66)$ \\
\hline \multirow[t]{2}{*}{06} & \multirow[t]{2}{*}{ Reference service } & $\mathbf{T}$ & $10(8.33)$ & $25(20.83)$ & $2(1.66)$ & $1(0.83)$ & $2(1.66)$ \\
\hline & & R.S & $25(20.83)$ & $24(20.0)$ & $6(5.0)$ & $20(16.66)$ & $5(4.16)$ \\
\hline \multirow[t]{2}{*}{07} & \multirow[t]{2}{*}{ Translation service } & $\mathbf{T}$ & $5(4.16)$ & $5(4.16)$ & $2(1.66)$ & $25(20.83)$ & $3(2.5)$ \\
\hline & & R.S & $2(1.66)$ & $3(2.5)$ & $10(8.33)$ & $45(37.50)$ & $10(8.33)$ \\
\hline \multirow[t]{2}{*}{08} & \multirow[t]{2}{*}{ ILL Service } & $\mathbf{T}$ & $6(5.0)$ & $4(3.33)$ & $2(1.66)$ & $8(6.66)$ & $20(16.66)$ \\
\hline & & R.S & $8(6.66)$ & $2(1.66)$ & $10(8.33)$ & $20(16.66)$ & $40(33.33)$ \\
\hline \multirow[t]{2}{*}{09} & \multirow{2}{*}{ Literature search } & $\mathbf{T}$ & $30(25.0)$ & $5(4.16)$ & $2(1.66)$ & $2(1.66)$ & $1(0.83)$ \\
\hline & & R.S & $60(50.00)$ & $10(8.33)$ & $5(4.16)$ & $3(2.5)$ & $2(1.66)$ \\
\hline \multirow[t]{2}{*}{10} & \multirow[t]{2}{*}{ Repackaging \& condensation } & $\mathbf{T}$ & $2(1.66)$ & $3(2.5)$ & $5(4.16)$ & $25(20.83)$ & $5(4.16)$ \\
\hline & & R.S & $3(2.5)$ & $5(4.16)$ & $4(3.33)$ & $50(41.66)$ & $18(15.0)$ \\
\hline \multirow[t]{2}{*}{11} & \multirow[t]{2}{*}{ Photocopying of periodical articles } & $\mathbf{T}$ & $10(8.33)$ & $15(12.50)$ & $10(8.33)$ & $5(4.16)$ & 0 \\
\hline & & R.S & $25(20.83)$ & $20(16.66)$ & $30(25.0)$ & $2(1.66)$ & $3(2.5)$ \\
\hline \multirow[t]{2}{*}{12} & \multirow[t]{2}{*}{ Abstracting service } & $\mathbf{T}$ & $10(8.33)$ & $20(16.66)$ & $5(4.16)$ & $2(1.66)$ & $3(2.5)$ \\
\hline & & R.S & $15(12.50)$ & $25(20.83)$ & $20(16.66)$ & $15(12.50)$ & $5(4.16)$ \\
\hline \multirow[t]{2}{*}{13} & \multirow[t]{2}{*}{ Indexing service } & $\mathbf{T}$ & $10(8.33)$ & $10(8.33)$ & $2(1.66)$ & $18(15.0)$ & 0 \\
\hline & & R.S & $15(12.50)$ & $10(8.33)$ & $30(25.0)$ & $23(19.16)$ & $2(1.66)$ \\
\hline
\end{tabular}


In social science $89.16 \%$ of the users always use the current awareness services, $5.83 \%$ sometimes. More than $79.16 \%$ of the users are use the selective dissemination services always, $5 \%$ sometimes and $15.83 \%$ never. More than $62.50 \%$ of the users sometimes used newspaper, $30 \%$ always. $58.33 \%$ respondents never used the patents information and also $24.16 \%$ sometimes. In social science $76.66 \%$ users need to reference service always and $17.50 \%$ sometimes. More than $93.33 \%$ teachers and research scholars use the library service most of them literature search, reference service always and also $58.33 \%$ sometimes used the translation service. $62.50 \%$ respondents sometimes used the repackaging \& consolidation and $19.16 \%$ never. More than $91.66 \%$ of the users always utilize the photocopy of periodical articles in the library. $79.16 \%$ respondents always used the indexing and abstracting service in the library.

Table 7. Ready to pay for information services

\begin{tabular}{|c|c|c|c|c|c|c|c|}
\hline S.N & \multicolumn{2}{|c|}{$\begin{array}{c}\text { Ready to Pay for Information } \\
\text { Service }\end{array}$} & Always & Often & Usually & Sometimes & Never \\
\hline \multirow[t]{2}{*}{01} & \multirow[t]{2}{*}{ CAS } & $\mathbf{T}$ & - & - & - & - & $40(33.33)$ \\
\hline & & R.S & - & - & - & - & $80(66.66)$ \\
\hline \multirow[t]{2}{*}{02} & \multirow[t]{2}{*}{ SDI } & $\mathbf{T}$ & - & - & - & - & $40(33.33)$ \\
\hline & & R.S & - & - & - & - & $80(66.66)$ \\
\hline \multirow[t]{2}{*}{03} & \multirow[t]{2}{*}{ Newspaper } & $\mathbf{T}$ & - & - & - & - & $40(33.33)$ \\
\hline & & R.S & - & - & - & - & $80(66.66)$ \\
\hline \multirow[t]{2}{*}{04} & \multirow[t]{2}{*}{ Patents information } & $\mathbf{T}$ & $5(4.16)$ & $10(8.33)$ & $10(8.33)$ & $10(8.33)$ & $5(4.16)$ \\
\hline & & R.S & $10(8.33)$ & $15(12.50)$ & $12(10.0)$ & $30(25.0)$ & $13(10.8)$ \\
\hline \multirow[t]{2}{*}{05} & \multirow{2}{*}{ Standards Inf. } & $\mathbf{T}$ & - & - & - & - & $40(33.33)$ \\
\hline & & R.S & - & - & - & - & $80(66.66)$ \\
\hline \multirow[t]{2}{*}{06} & \multirow[t]{2}{*}{ Reference service } & $\mathbf{T}$ & - & - & - & $35(29.16)$ & $5(4.16)$ \\
\hline & & R.S & - & - & $10(8.33)$ & $55(66.0)$ & $5(4.16)$ \\
\hline \multirow[t]{2}{*}{07} & \multirow[t]{2}{*}{ Translation service } & $\mathbf{T}$ & - & - & - & $30(25.0)$ & $10(8.33)$ \\
\hline & & R.S & - & $10(8.33)$ & $15(12.50)$ & $45(37.5)$ & $10(8.33)$ \\
\hline \multirow[t]{2}{*}{08} & \multirow[t]{2}{*}{ ILL Service } & $\mathbf{T}$ & - & - & $10(8.33)$ & $25(20.83)$ & $5(4.16)$ \\
\hline & & R.S & - & $5(4.16)$ & $30(25.0)$ & $35(29.16)$ & $10(8.33)$ \\
\hline \multirow[t]{2}{*}{09} & \multirow[t]{2}{*}{ Literature search } & $\mathbf{T}$ & - & - & - & - & $40(33.33)$ \\
\hline & & R.S & - & - & - & - & $80(66.66)$ \\
\hline \multirow[t]{2}{*}{10} & \multirow[t]{2}{*}{ Repackaging \& condensation } & $\mathbf{T}$ & - & - & $10(8.33)$ & $25(20.83)$ & $5(4.16)$ \\
\hline & & R.S & - & - & $5(4.16)$ & $20(16.66)$ & $55(45.83)$ \\
\hline \multirow[t]{2}{*}{11} & \multirow{2}{*}{$\begin{array}{l}\text { Photocopying of periodical } \\
\text { articles }\end{array}$} & $\mathbf{T}$ & $10(8.33)$ & $5(4.16)$ & $5(4.16)$ & $15(12.50)$ & $5(4.16)$ \\
\hline & & R.S & $20(16.66)$ & $10(8.33)$ & $30(25.0)$ & $10(8.33)$ & $10(8.33)$ \\
\hline \multirow[t]{2}{*}{12} & \multirow[t]{2}{*}{ Abstracting service } & $\mathbf{T}$ & - & - & - & - & $40(33.33)$ \\
\hline & & R.S & - & - & - & - & $80(66.66)$ \\
\hline \multirow[t]{2}{*}{13} & \multirow[t]{2}{*}{ Indexing service } & $\mathbf{T}$ & - & - & $10(8.33)$ & $25(20.83)$ & $5(4.16)$ \\
\hline & & R.S & - & - & $15(12.50)$ & $40(33.33)$ & $25(20.83)$ \\
\hline
\end{tabular}

Table. 7 reveal the respondents ready to pay for kurukshetra university library regarding various information services of marketing. $100 \%$ respondents are never pay to information services i.e. CAS, SDI, newspaper, standards information, literature search and abstracting service available in library. $66.66 \%$ users are always paid to charge the photocopy of periodicals in library and also $51.66 \%$ users always pay to patents information and maximum social science teachers and research scholars sometimes pay to information services i.e. reference service, translation service, inter library loan service, and indexing service in library.

Table 8. User need to information products

\begin{tabular}{|l|l|c|c|c|c|c|c|}
\hline S.N & \multicolumn{2}{|c|}{$\begin{array}{c}\text { User Need to Information } \\
\text { Products }\end{array}$} & Always & Often & Usually & Sometimes & Never \\
\hline 01 & Directories & $\mathbf{T}$ & $2(1.66)$ & - & - & - & $38(31.66)$ \\
\cline { 3 - 8 } & & $\mathbf{R . S}$ & $5(4.16)$ & $15(12.50)$ & $10(8.33)$ & $10(8.33)$ & $40(33.33)$ \\
\hline 02 & \multirow{2}{*}{ Information Bulletin } & $\mathbf{T}$ & $10(8.33)$ & $15(12.50)$ & $5(4.16)$ & $5(4.16)$ & $5(4.16)$ \\
\cline { 3 - 8 } & & R.S & $20(16.66)$ & $22(18.33)$ & $18(15.0)$ & $12(10.0)$ & $8(6.66)$ \\
\hline 03 & News Bulletin & $\mathbf{T}$ & $5(4.16)$ & $10(8.33)$ & $5(4.16)$ & $20(16.66)$ & - \\
\hline \hline
\end{tabular}


Marketing of Information Products \& Services in Kurukshetra University Library in the Disciplines of

\begin{tabular}{|c|c|c|c|c|c|c|c|}
\hline & & R.S & $10(8.33)$ & $20(16.66)$ & $10(8.33)$ & $30(25.0)$ & $10(8.33)$ \\
\hline \multirow[t]{2}{*}{04} & \multirow[t]{2}{*}{ Abstracts lists } & $\mathbf{T}$ & $10(8.33)$ & $5(4.16)$ & $5(4.16)$ & $5(4.16)$ & $15(12.50)$ \\
\hline & & R.S & $15(12.50)$ & $10(8.33)$ & $15(12.50)$ & $10(8.33)$ & $30(25.0)$ \\
\hline \multirow[t]{2}{*}{05} & \multirow[t]{2}{*}{ Data analysis statistics } & $\mathbf{T}$ & $5(4.16)$ & $10(8.33)$ & $5(4.16)$ & $20(16.66)$ & - \\
\hline & & R.S & $10(8.33)$ & $20(16.66)$ & $10(8.33)$ & $30(25.0)$ & $10(8.33)$ \\
\hline \multirow[t]{2}{*}{06} & \multirow[t]{2}{*}{ Bibliographic lists } & $\mathbf{T}$ & $10(8.33)$ & $5(4.16)$ & $5(4.16)$ & $5(4.16)$ & $15(12.50)$ \\
\hline & & R.S & $15(12.50)$ & $10(8.33)$ & $15(12.50)$ & $10(8.33)$ & $30(25.0)$ \\
\hline \multirow[t]{2}{*}{07} & \multirow[t]{2}{*}{ Current awareness bulletins } & $\mathbf{T}$ & $15(12.50)$ & $10(8.33)$ & $10(8.33)$ & $5(4.16)$ & - \\
\hline & & R.S & $25(20.83)$ & $10(8.33)$ & $20(16.66)$ & $10(8.33)$ & $15(12.50)$ \\
\hline \multirow[t]{2}{*}{08} & \multirow[t]{2}{*}{ SDI bulletins } & $\mathbf{T}$ & $5(4.16)$ & $10(8.33)$ & $5(4.16)$ & $20(16.66)$ & - \\
\hline & & R.S & $10(8.33)$ & $20(16.66)$ & $10(8.33)$ & $30(25.0)$ & $10(8.33)$ \\
\hline \multirow[t]{2}{*}{09} & \multirow[t]{2}{*}{ Literature search } & $\mathbf{T}$ & $10(8.33)$ & $5(4.16)$ & $5(4.16)$ & $5(4.16)$ & $15(12.50)$ \\
\hline & & R.S & $15(12.50)$ & $10(8.33)$ & $15(12.50)$ & $10(8.33)$ & $30(25.0)$ \\
\hline \multirow[t]{2}{*}{10} & \multirow[t]{2}{*}{ New additions lists } & $\mathbf{T}$ & $10(8.33)$ & $10(8.33)$ & $5(4.16)$ & $10(8.33)$ & $5(4.16)$ \\
\hline & & R.S & $12(10.0)$ & $30(25.0)$ & $8(6.66)$ & $15(12.50)$ & $15(12.50)$ \\
\hline
\end{tabular}

Table 8 . shows that only $65 \%$ of the users reported that the directories is never use while only $5.83 \%$ of the users that it is always use for their areas of activity. More than $50 \%$ of the social science respondents used those information products such as news bulletin, data analysis, bibliographic lists, SDI, and literature search are always and $41.66 \%$ sometimes. It shows the market potentialities of these products in the kurukshetra university library. $75 \%$ teachers and research scholars stated that the information bulletins are always used in the library. Abstracts lists is always useful to $50 \%$ of the users. $62.50 \%$ of the users stated that the new additions lists in library are always useful and current awareness bulletin is valuable to $75 \%$ of the respondents.

Table 9. Ready to pay for information services

\begin{tabular}{|c|c|c|c|c|c|c|c|}
\hline S.N & \multicolumn{2}{|c|}{$\begin{array}{l}\text { User Need to Information } \\
\text { Products }\end{array}$} & Always & Often & Usually & Sometimes & Never \\
\hline \multirow[t]{2}{*}{01} & \multirow[t]{2}{*}{ Directories } & $\mathbf{T}$ & - & - & - & - & $40(33.33)$ \\
\hline & & R.S & - & - & - & - & $80(66.66)$ \\
\hline \multirow[t]{2}{*}{02} & \multirow[t]{2}{*}{ Information Bulletin } & $\mathbf{T}$ & - & - & - & $30(25.0)$ & $10(8.33)$ \\
\hline & & R.S & - & $10(8.33)$ & $15(12.50)$ & $45(37.5)$ & $10(8.33)$ \\
\hline \multirow[t]{2}{*}{03} & \multirow[t]{2}{*}{ News Bulletin } & $\mathbf{T}$ & - & - & - & - & $40(33.33)$ \\
\hline & & R.S & - & - & - & - & $80(66.66)$ \\
\hline \multirow[t]{2}{*}{04} & \multirow[t]{2}{*}{ Abstracts lists } & $\mathbf{T}$ & $10(8.33)$ & $5(4.16)$ & $5(4.16)$ & $15(12.50)$ & $5(4.16)$ \\
\hline & & R.S & $20(16.66)$ & $10(8.33)$ & $30(25.0)$ & $10(8.33)$ & $10(8.33)$ \\
\hline \multirow[t]{2}{*}{05} & \multirow[t]{2}{*}{ Data analysis statistics } & $\mathbf{T}$ & - & - & - & - & $40(33.33)$ \\
\hline & & R.S & - & - & - & - & $80(66.66)$ \\
\hline \multirow[t]{2}{*}{06} & \multirow[t]{2}{*}{ Bibliographic lists } & $\mathbf{T}$ & $5(4.16)$ & $10(8.33)$ & $5(4.16)$ & $20(16.66)$ & - \\
\hline & & R.S & $10(8.33)$ & $20(16.66)$ & $10(8.33)$ & $30(25.0)$ & $10(8.33)$ \\
\hline \multirow[t]{2}{*}{07} & \multirow[t]{2}{*}{ Current awareness bulletins } & $\mathbf{T}$ & $5(4.16)$ & $10(8.33)$ & $10(8.33)$ & $10(8.33)$ & $5(4.16)$ \\
\hline & & R.S & $10(8.33)$ & $15(12.50)$ & $10(8.33)$ & $32(26.66)$ & $13(10.8)$ \\
\hline \multirow[t]{2}{*}{08} & \multirow[t]{2}{*}{ SDI bulletins } & $\mathbf{T}$ & - & - & $10(8.33)$ & $25(20.83)$ & $5(4.16)$ \\
\hline & & R.S & - & - & $5(4.16)$ & $20(16.66)$ & $55(45.83)$ \\
\hline \multirow[t]{2}{*}{09} & \multirow[t]{2}{*}{ Literature search } & $\mathbf{T}$ & - & - & - & - & $40(33.33)$ \\
\hline & & R.S & - & - & - & - & $80(66.66)$ \\
\hline \multirow[t]{2}{*}{10} & \multirow[t]{2}{*}{ New additions lists } & $\mathbf{T}$ & - & - & - & $30(25.0)$ & $10(8.33)$ \\
\hline & & R.S & - & $10(8.33)$ & $15(12.50)$ & $45(37.5)$ & $10(8.33)$ \\
\hline
\end{tabular}

Table. 9 reveal the respondents ready to pay for kurukshetra university library regarding various information products of marketing. $100 \%$ respondents are never pay to information products i.e. directories, news bulletin, data analysis statistics and literature searcher available in library. 50\% users are always paid to charge the current awareness \& bibliographic lists both in library and also $66.66 \%$ users always pay to abstracts lists and maximum social science teachers and research scholars sometimes pay to information products i.e. information bulletin, SDI bulletin, and new additions lists in library. 
Table 10. Awareness of library and Information Services

\begin{tabular}{|c|c|c|c|c|c|c|c|}
\hline \multirow{3}{*}{\multicolumn{2}{|c|}{$\begin{array}{l}\text { Information } \\
\text { Services }\end{array}$}} & \multicolumn{6}{|c|}{ Awareness } \\
\hline & & \multicolumn{2}{|c|}{$\begin{array}{c}\text { Aware of \& } \\
\text { used }\end{array}$} & \multicolumn{2}{|c|}{ Aware of but not used } & \multicolumn{2}{|c|}{$\begin{array}{c}\text { Not aware } \\
\text { of }\end{array}$} \\
\hline & & frequency & Percent & frequency & Percent & frequency & Percent \\
\hline \multirow[t]{2}{*}{ Leading of Books } & $\mathbf{T}$ & 32 & (26.66) & 8 & $(6.66)$ & - & - \\
\hline & R.S & 75 & $(62.50)$ & 5 & $(4.16)$ & & \\
\hline \multirow[t]{2}{*}{ Reservation of books } & $T$ & 30 & $(25.0)$ & 8 & 6.66 & 2 & 1.66 \\
\hline & R.S & 65 & $(54.16)$ & 10 & 8.33 & 5 & 4.16 \\
\hline \multirow[t]{2}{*}{ Renewal of books } & $\mathbf{T}$ & 25 & $(20.83)$ & 10 & 8.33 & 5 & 4.16 \\
\hline & R.S & 70 & $(58.33)$ & 8 & 6.66 & 2 & 1.66 \\
\hline \multirow[t]{2}{*}{ SDI service } & $\mathbf{T}$ & 10 & 8.33 & 25 & 20.83 & 5 & 4.16 \\
\hline & R.S & 10 & 8.33 & 60 & 50.0 & 10 & 8.33 \\
\hline \multirow[t]{2}{*}{ CAS Service } & $\mathbf{T}$ & 15 & 12.5 & 20 & 16.66 & 5 & 4.16 \\
\hline & R.S & 35 & 29.16 & 35 & 29.16 & 10 & 8.33 \\
\hline \multirow[t]{2}{*}{ Indexing Service } & $\mathbf{T}$ & 5 & 4.16 & 25 & 20.83 & 10 & 8.33 \\
\hline & R.S & 10 & 8.33 & 45 & 37.5 & 25 & 20.83 \\
\hline \multirow[t]{2}{*}{ Abstracting Service } & $\mathbf{T}$ & 10 & 8.33 & 25 & 20.83 & 5 & 4.16 \\
\hline & R.S & 15 & 12.5 & 45 & 37.5 & 20 & 16.66 \\
\hline \multirow[t]{2}{*}{ Bibliographic Service } & $\mathbf{T}$ & 13 & 10.83 & 25 & 20.83 & 2 & 1.66 \\
\hline & R.S & 25 & 20.83 & 40 & 33.33 & 15 & 12.5 \\
\hline \multirow[t]{2}{*}{ User Orientation } & $\mathbf{T}$ & 15 & 12.5 & 20 & 16.66 & 5 & 4.16 \\
\hline & R.S & 30 & 25.0 & 45 & 37.5 & 5 & 4.16 \\
\hline \multirow[t]{2}{*}{ Reprographic Service } & $\mathbf{T}$ & 30 & 25.0 & 10 & 8.33 & - & - \\
\hline & R.S & 60 & 50.0 & 10 & 8.33 & 10 & 8.33 \\
\hline \multirow[t]{2}{*}{ Digital repository } & $\mathbf{T}$ & 25 & 20.83 & 10 & 8.33 & 5 & 4.16 \\
\hline & R.S & 35 & 29.16 & 40 & 33.33 & 5 & 4.16 \\
\hline \multirow[t]{2}{*}{ Reference Service } & $\mathbf{T}$ & 25 & 20.83 & 15 & 12.5 & - & - \\
\hline & R.S & 40 & 33.33 & 20 & 16.66 & 20 & 16.66 \\
\hline \multirow[t]{2}{*}{ Document delivery } & $\mathbf{T}$ & 10 & 8.33 & 25 & 20.83 & 5 & 4.16 \\
\hline & R.S & 15 & 12.5 & 40 & 33.33 & 25 & 20.83 \\
\hline \multirow[t]{2}{*}{ Translation Service } & $\mathbf{T}$ & 8 & 6.66 & 30 & 25.0 & 2 & 1.66 \\
\hline & R.S & 10 & 8.33 & 50 & 41.66 & 20 & 16.66 \\
\hline \multirow[t]{2}{*}{ ILL Service } & $\mathbf{T}$ & 5 & 4.16 & 30 & 25.0 & 5 & 4.16 \\
\hline & R.S & 10 & 8.33 & 60 & 50.0 & 10 & 8.33 \\
\hline \multirow[t]{2}{*}{ CD/DVD based service } & $\mathbf{T}$ & 30 & 25.0 & 5 & 4.16 & 5 & 4.16 \\
\hline & R.S & 40 & 33.33 & 30 & 25.0 & 10 & 8.33 \\
\hline \multirow[t]{2}{*}{ Internet service } & $\mathbf{T}$ & 40 & 33.33 & - & - & - & - \\
\hline & R.S & 60 & 50.0 & 20 & 16.66 & - & - \\
\hline \multirow[t]{2}{*}{ Institutional Repository } & $\mathbf{T}$ & 10 & 8.33 & 25 & 20.83 & 5 & 4.16 \\
\hline & R.S & 20 & 16.66 & 48 & 40.0 & 12 & 10.0 \\
\hline \multirow[t]{2}{*}{ Document scanning } & $T$ & 10 & 8.33 & 30 & 25.0 & - & - \\
\hline & R.S & 5 & 4.16 & 70 & 58.33 & 5 & 4.16 \\
\hline Document printing & $\mathbf{T}$ & 35 & 29.16 & 5 & 4.16 & - & - \\
\hline & R.S & 25 & 20.83 & 50 & 41.66 & 5 & 4.16 \\
\hline
\end{tabular}

Table 10. shows that more than $92 \%$ of the respondents are aware of the basic library services among which leading of books $89.16 \%$, reservation of books $79.16 \%$ and also same renewal of books. More than $70.83 \%$ users are aware but not in use SDI service in library. Among the readers awareness services but not in use such as $58.33 \%$ indexing service, abstracting service, and also $54.16 \%$ of the users are received other bibliographic service, user orientation and document delivery services. In social science $75 \%$ respondents are aware and use the reprographic service in the library. Among the digital repository, $50 \%$ of the respondents are used and aware about digital repository service and $54.16 \%$ about reference service. Document printing service utilized by $50 \%$ of the respondents while document scanning service by only $12.5 \%$ of the users. $83.33 \%$ of the users are aware 
and use the internet service in kurukshetra university library. Even though digital services such as CD/DVD based services $87.50 \%$ and institutional repository service $90 \%$ are aware of by the respondents but only $45 \%$ are utilized.

Table 11. Common Problem faced by the users to access the Information Resources

\begin{tabular}{|c|c|c|c|c|c|c|}
\hline \multicolumn{2}{|l|}{$\begin{array}{l}\text { Common problem faced by } \\
\text { the users }\end{array}$} & $\begin{array}{l}\text { Strongly } \\
\text { Agree }\end{array}$ & Agree & $\begin{array}{l}\text { Not } \\
\text { Sure }\end{array}$ & Disagree & $\begin{array}{l}\text { Strongly } \\
\text { Disagree }\end{array}$ \\
\hline \multirow{2}{*}{$\begin{array}{l}\text { Location of the library is inconvenient to } \\
\text { access }\end{array}$} & $\mathbf{T}$ & - & $5(4.16)$ & - & - & - \\
\hline & R.S & - & $10(8.33)$ & - & - & - \\
\hline \multirow[t]{2}{*}{ Working hours of the library is inconvenient } & $\mathbf{T}$ & $25(20.83)$ & $10(8.33)$ & $5(4.16)$ & - & - \\
\hline & R.S & $35(29.16)$ & $20(16.66)$ & $10(8.33)$ & - & - \\
\hline \multirow{2}{*}{$\begin{array}{l}\text { Library environment is not congenial for } \\
\text { serious study }\end{array}$} & $\mathbf{T}$ & - & - & $10(8.33)$ & - & - \\
\hline & R.S & - & - & $20(16.66)$ & - & - \\
\hline \multirow[t]{2}{*}{ Library collection is inadequate } & $\mathbf{T}$ & $10(8.33)$ & $5(4.16)$ & $10(8.33)$ & - & - \\
\hline & R.S & $35(29.16)$ & $10(8.33)$ & $5(4.16)$ & - & - \\
\hline \multirow[t]{2}{*}{ Library does not provide current inf. } & $\mathbf{T}$ & - & - & $15(12.5)$ & - & - \\
\hline & R.S & - & - & $30(25.0)$ & - & - \\
\hline \multirow[t]{2}{*}{ Library staff are not helpful } & $\mathbf{T}$ & - & - & $20(16.66)$ & - & - \\
\hline & R.S & - & $15(12.5)$ & $50(41.66)$ & - & - \\
\hline \multirow[t]{2}{*}{ Get information From other libraries } & $\mathbf{T}$ & $30(25.0)$ & $5(4.16)$ & $5(4.16)$ & & - \\
\hline & R.S & $45(37.50)$ & $5(4.16)$ & $20(16.66)$ & & \\
\hline
\end{tabular}

Table 11. indicates that $50 \%$ of the users are strongly agreed by working hours of the library are inconvenient, $25 \%$ agree. $37.50 \%$ of the social science teachers \& research scholars are strongly agree reported the inability of the library collection to provide current or specialized information and $12.50 \%$ agree with the statement. Most of the $58.33 \%$ respondents are strongly agreed get the information from other libraries by research work and current information in the field of subject.

\section{Finding Of The Survey}

- Marketing of information products and services in kurukshetra university library in the disciplines of social science users used more by males i.e. by $53.57 \%$ than female users.

- Marketing of information products and services used by the library research scholars $66.66 \%$ and professors $15 \%$ than the junior faculty members.

- $\quad 43.33 \%$ respondents were always using the library daily and $14.16 \%$ sometimes and also $14.16 \%$ users were always using the library once in a week, $6.66 \%$ twice in a week.

- $20.83 \%$ respondents were always using the library by occasionally.

- In social science $29.16 \%$ respondents were 30 to 2 hours time spends in the library, $26.66 \%$ respondents were sometimes. Only $23.33 \%$ of the users spend less than 30 minutes, $20.83 \%$ sometimes.

- $94.16 \%$ users were using the library for research needs, $70.83 \%$ users were education purpose for using the library.

- $54.16 \%$ social science respondents were always current information regarding using the library, and $29.16 \%$ sometimes.

- In social science $79.16 \%$ users were using the journals/articles in kurukshetra university library.

- $89.16 \%$ of the users always using the current awareness services and $5.83 \%$ sometimes.

- More than $79.16 \%$ of the users were always using the SDI service in the library, only $5 \%$ sometimes and $15.83 \%$ never.

- Most of the respondents $76.66 \%$ were always using the reference service and $17.50 \%$ sometimes in the library

- More than $93.33 \%$ teachers and research scholars always use the library service most of them literature search.

- $79.16 \%$ respondents always used the indexing and abstracting service in the library.

- $100 \%$ respondents were never to pay for information services i.e. CAS, SDI, newspaper, standards information, literature search and abstracting service available in library.

- $66.66 \%$ users were always paid to charge the photocopy of periodicals in library. 
- $51.66 \%$ users always paid to patents information and maximum social science teachers and research scholars sometimes pay to information services i.e. reference service, translation service, inter library loan service, and indexing service in library.

- $65 \%$ of the users reported that the directories were never used while only $5.83 \%$ of the users that it was always used for their areas of activity.

- $50 \%$ of the social science respondents used those information products such as news bulletin, data analysis, bibliographic lists, SDI, and literature search were always and $41.66 \%$ sometimes.

- $\quad 75 \%$ teachers and research scholars stated that the information bulletins were always used in the library.

- $100 \%$ respondents never paid to information products i.e. directories, news bulletin, data analysis statistics and literature searcher in library.

- $50 \%$ users were always paid to charge the current awareness \& bibliographic lists in kurukshetra university library.

- $66.66 \%$ users always paid to abstracts lists and maximum social science users sometimes paid to information products i.e. information bulletin, SDI bulletin, and new additions lists in library.

- More than $92 \%$ of the respondents were awared of the basic library services among which leading of books $89.16 \%$, reservation of books $79.16 \%$ and also same renewal of books.

- More than $70.83 \%$ users were awared but not in use SDI service in library.

- $50 \%$ of the respondents were used and aware about digital repository service and $54.16 \%$ about reference service.

- Document printing service utilized by $50 \%$ of the respondents while document scanning service by only $12.5 \%$ of the users. $83.33 \%$ of the users were awared and use the internet service in kurukshetra university library.

- CD/DVD based services $87.50 \%$ and institutional repository service $90 \%$ were awared of by the respondents but only $45 \%$ were utilized.

- $50 \%$ of the users were strongly agreed by working hours of the library were inconvenient, $25 \%$ agreed.

- $\quad 37.50 \%$ of the social science teachers \& research scholars were strongly agreed reported the inability of the library collection to provide current or specialized information and $12.50 \%$ agreed with the statement.

- $58.33 \%$ respondents were strongly agreed to get the information from other libraries by research work and current information in the field of subject.

Based on the findings, the following Suggestions are put forward to improve the marketing of information products and services in kurukshetra university library.

- An intensive effort was required from the part of the top management of the library, and authorities of the concerned universities to overcome the identified weakness.

- To improve the library personnel should be made aware of the concepts and principles of modern marketing. So provide better provision for the library staff to attend in-service and career advancement courses and also most of the respondents were willing to pay for information products \& services imply that they rely on the quality of information products than the existing products, which were freely available.

- Kurukshetra university library have to restructure or develop some of the existing products and services and to start new services based on market analysis.

- Most of respondents were suggested that Kurukshetra University library should take necessary steps to install plasma or LCD screen in the library entrance hall to display notices and information (photographs, videos etc.) of their information services and products.

- Kurukshetra university library should be adopted some of the marketing and promotional strategies including publications, programmers of events, media and effective presentation of information products and services through the library website.

- Library web 24/7 ( 24 hours 7 days in a week) access, initiating information desk with liaison librarians, information literacy programmers, establishment of virtual reference-telephone, e-mail and chat reference service were the major ways to increase the marketing orientation in the library.

- Staff should be facilitated through workshops and seminars to acquire and sharpen ICT skills, which will enable them to market the information services and products of the university libraries in Kerala by designing the websites and portals that will enhance the image of the library.

\section{Acknowledgements}

First and foremost, I would like to thank the almighty God (Jesus Christ) the most beneficent and merciful, who blessed me for completing this work. It is not possible to record in words the inspirational guidance of my father Sh. Som Nath kapoor, Mother Shanti devi \& also Dr. Joginder Singh (Associate Prof.), Dept. of library \& information 
Science from Kurukshetra University Kurukshetra. I am also thanks to Dr. Maninder (Admin) Head, Swift Group of

Colleges the inspirational guidance.

\section{References}

[1]. N. Aharony. Librarian's attitudes towards marketing library services. Journal of Librarianship and Information Science. 41(1), 2009, 39-50.

[2]. Amritpal Kaur. Marketing of information services and products in University Libraries of Punjab and Chandigarh. Electronic Journal of Academic and Special Librarianship 8(3), 2007.

[3]. B. Anagreh. Modifying the marketing mix of library services in accordance with the market mechanism: an applied study at Jordanian Universities. International journal of academic research in business and social sciences 2(10), 2012, 218-226.

[4]. S. Ganguly, D. C, Kar. Marketing: A critical policy for today's information centre. DESIDOC Bulletin of Information Technology 22(3), 2002., 15-25

[5]. Dinesh K. Gupta. Marketing Library and Information Services. University of Montreal, 2010. 3553-3560.

[6]. Shiva. Kanaujia. Marketing of information products and services in Indian R \& D library and information centres. Library management 25(8/9), 2004, 350-360.

[7]. C. M. Koontz, P. E, Rockwood. Developing performance measures within a Marketing frame of reference. New Library World 102 (1163/1164), 2001, 146-153.

[8]. P. Kotler, A. R, Andreasen. Strategic Marketing for Non-Profit Organization. Companion Encyclopedia of Marketing: London. 1995, 930.

[9]. P. Kotler. Marketing management analysis planning implementation and control. Prentice Hall of India: New Delhi, $1996,12-13$.

[10]. E. Makori. Making university research libraries in Kenya the destination for the user population. Library Review 59 (7), 2011, 548557 .

[11]. B. R. Mandal, A. K, Poddar and J. C, Choudhury. Marketing of INSDOC Services: A Report Libraries and Information Centres as Profit Making Institution: New Delhi. 1998, 88.

[12]. M.N. Munshi. Marketing of information products and services for special libraries in Bangladesh. University of Dhaka, 2008, 84-96.

[13]. C. Neuhaus, K. Snowden. Public relations for a university library: A marketing programmer is born. Library Management 24 (4-5), 2006, 193-203.

[14]. S. N. Pandya. Information marketing: Need of the hour. Library Practices for Effective Management: ILA Seminar Papers. 47th All India Library Conference, 20-23 Dec., 2001, Warrangal. Delhi: Indian Library Association. 2001, 358-67.

[15]. S.O. Popoola. Faculty awareness and use of library information products and service in Nigerian universities. Malaysian Journal of Library \& Information Science 13(1), 2008, 91-102.

[16]. R. Sharma, P. K, Chaudhary. Marketing value added management information to user community: A case study of AIMA Library. Electronic Information Environment and Library Services: A Contemporary Paradigm. 48th All India Library Conference, 22-23 Jan. 2003, Bangalore. Delhi: Indian Library Association 10(1), 2003, 438-46.

[17]. W.J. Stanton. Fundamentals of marketing. McGraw-Hill: New York. 1981, 101-104

[18]. P.G. Tadasad, S. C, Talikoti. Awareness and utilization of resources services and facilities of city central libraries: A users' survey of City Central Library Gulbarga. ILA Bulletin 36 (3), 2000, 80-86.

[19]. Vij, Rajiv. Marketing of library products and services in India. International indexed \& referred research journal 3(34), 2012 , 89-91.

\section{Personal information}

Appendix - 1

Name:

Department:

Sex: Female/Male

Status: (tick one): Professor/Reader/Lecturer/Research scholar

\section{Library Services \& Information products}

\section{Do you use the library?}

\begin{tabular}{|l|l|l|l|l|l|}
\hline Use the Library & Always & Often & Usually & Sometimes & Never \\
\hline Daily & & & & & \\
\hline Once in a Week & & & & & \\
\hline Twice in a week & & & & & \\
\hline Thrice in a week & & & & & \\
\hline Four times in a week & & & & & \\
\hline Five times in a week & & & & & \\
\hline Occasionally & & & & & \\
\hline
\end{tabular}

\section{* Average time spent in the library on a visit}

\begin{tabular}{|l|l|l|l|l|l|}
\hline Time Spent & Always & Often & Usually & Sometimes & Never \\
\hline Less than 30 Min. & & & & \\
\hline Between 30 Min. \& 2 hours & & & & & \\
\hline Between 2 \& 5 hours & & & & & \\
\hline More than 5 hours & & & & & \\
\hline
\end{tabular}

* Please mention the Purpose for which you use the library? 
Marketing of Information Products \& Services in Kurukshetra University Library in the Disciplines of

\begin{tabular}{|l|l|l|l|l|l|}
\hline Purpose of Use & Always & Often & Usually & Sometimes & Never \\
\hline Research needs & & & & & \\
\hline Education & & & & & \\
\hline Current Information & & & & & \\
\hline Photocopy & & & & & \\
\hline Newspaper & & & & & \\
\hline Journals & & & & & \\
\hline
\end{tabular}

Please mention the information services that you are need/expect to find?
\begin{tabular}{|l|l|l|l|l|l|}
\hline Information Services & Always & Often & Usually & Sometimes & Never \\
\hline Current Awareness service & & & & & \\
\hline Selective dissemination of information & & & & & \\
\hline Newspaper clippings & & & & & \\
\hline Patents information & & & & & \\
\hline Standards information & & & & & \\
\hline Reference services & & & & & \\
\hline Translation services & & & & & \\
\hline Inter library loan services & & & & & \\
\hline Literature search & & & & & \\
\hline Repackaging \& condensation service & & & & & \\
\hline Photocopying of periodical articles & & & & & \\
\hline Abstracting Services & & & & & \\
\hline Indexing services & & & & & \\
\hline
\end{tabular}

* If the available information services are not developed and comprehensive, are you ready to pay fees for developed and comprehensive services?

Yes/No

(If yes, please indicate your preference for Information Services that you are ready to pay fees for mention it)

\begin{tabular}{|l|l|l|l|l|l|}
\hline Information Services & Always & Often & Usually & Sometimes & Never \\
\hline Current Awareness service & & & & & \\
\hline Selective dissemination of information & & & & & \\
\hline Newspaper clippings & & & & & \\
\hline Patents information & & & & & \\
\hline Standards information & & & & & \\
\hline Abstracting services & & & & & \\
\hline Indexing services & & & & & \\
\hline Reference services & & & & & \\
\hline Translation services & & & & & \\
\hline Inter library loan services & & & & & \\
\hline Literature search & & & & & \\
\hline Repackaging \& condensation service & & & & & \\
\hline Photocopying of periodical articles & & & & & \\
\hline
\end{tabular}

* Please mentions against the information products that you are need/expect to find?

\begin{tabular}{|c|c|c|c|c|c|}
\hline Information Products & Always & Often & Usually & Sometimes & Never \\
\hline \multicolumn{6}{|l|}{ Information Bulletin } \\
\hline \multicolumn{6}{|l|}{ Abstracts lists } \\
\hline \multicolumn{6}{|l|}{ Data analysis statistics } \\
\hline \multicolumn{6}{|l|}{ Bibliographic lists } \\
\hline \multicolumn{6}{|l|}{ Literature search } \\
\hline New additions lists & & & & & \\
\hline
\end{tabular}

* If the available information products are not developed and comprehensive, are you ready to pay fees for developed and comprehensive products: $\quad$ Yes/No

(If yes, please indicate your preference for Information Products that you are ready to pay fees for mention it.)

\begin{tabular}{|l|l|l|l|l|l|}
\hline Information Products & Always & Often & Usually & Sometimes & Never \\
\hline Directories & & & & & \\
\hline Information Bulletin & & & & & \\
\hline News Bulletin & & & & & \\
\hline
\end{tabular}




\begin{tabular}{|l|l|l|l|l|l|}
\hline Abstracts lists & & & & & \\
\hline Data analysis statistics & & & & & \\
\hline Bibliographic lists & & & & & \\
\hline Current awareness bulletins & & & & & \\
\hline SDI bulletins & & & & & \\
\hline Literature search & & & & & \\
\hline New additions lists & & & & & \\
\hline
\end{tabular}

* Listed below are various services. Please tick the services you are aware of your present work activity involved.

\begin{tabular}{|c|c|c|c|}
\hline \multirow{2}{*}{ Information Services } & \multicolumn{3}{|c|}{ Awareness } \\
\hline & Aware of \& used & Aware of but not used & Not aware of \\
\hline \multicolumn{4}{|l|}{ Leading of Books } \\
\hline \multicolumn{4}{|l|}{ Reservation of books } \\
\hline \multicolumn{4}{|l|}{ Renewal of books } \\
\hline \multicolumn{4}{|l|}{ SDI service } \\
\hline \multicolumn{4}{|l|}{ CAS Service } \\
\hline \multicolumn{4}{|l|}{ Indexing Service } \\
\hline \multicolumn{4}{|l|}{ Abstracting Service } \\
\hline \multicolumn{4}{|l|}{ Bibliographic Service } \\
\hline \multicolumn{4}{|l|}{ User Orientation } \\
\hline \multicolumn{4}{|l|}{ Reprographic Service } \\
\hline \multicolumn{4}{|l|}{ Digital repository } \\
\hline \multicolumn{4}{|l|}{ Reference Service } \\
\hline \multicolumn{4}{|l|}{ Document delivery } \\
\hline \multicolumn{4}{|l|}{ Translation Service } \\
\hline \multirow{2}{*}{\multicolumn{4}{|c|}{$\begin{array}{l}\text { ILL Service } \\
\text { CD/DVD based service }\end{array}$}} \\
\hline & & & \\
\hline \multicolumn{4}{|l|}{ Internet service } \\
\hline \multicolumn{4}{|l|}{ Institutional Repository } \\
\hline \multicolumn{4}{|l|}{ Document scanning } \\
\hline Document printing & & & \\
\hline
\end{tabular}

* What are the common problems faced by the users to access the information resources?

(SA-Strongly Agree; A-Agree; NS-Not Sure; D-Disagree; SD-Strongly Disagree)

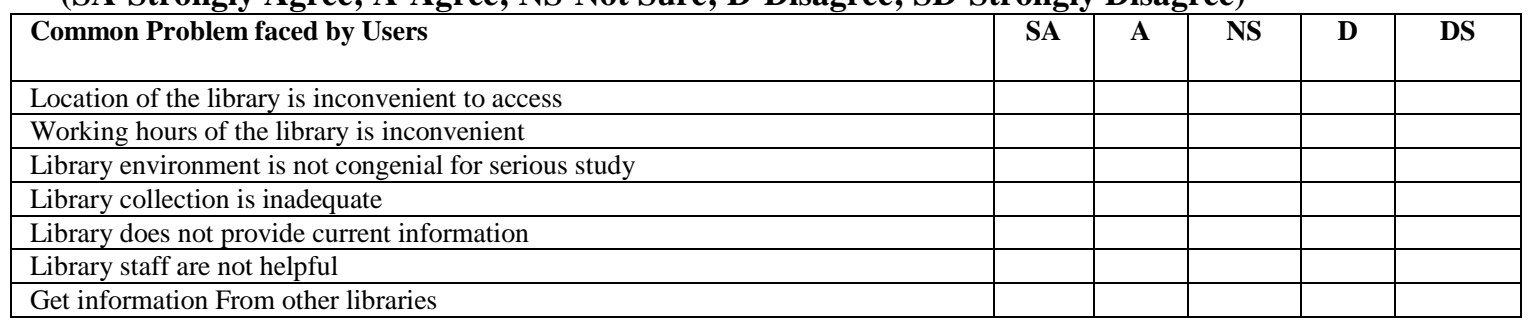

* Any other suggestion to improve library services and products

\section{Signature}

\section{Thanks for your cooperation}

